\title{
Towards a New Map of Africa through Rastafari 'Works'
}

\author{
Jahlani Niaah*
}

\begin{abstract}
This paper seeks to broaden the notion of the African Public sphere to include the historical Diaspora by highlighting the works of Mortimo Planno, cultural historian - Rastafari luminary and plenipotentiary - in closing the void between Africa and its Diaspora, through examining Planno's definition of the African public sphere, as articulated in his general writings and main text: 'The Earth Most Strangest Man', as well as travelogues articulating his discourse on Back-to-Africa. Mortimo Planno is credited as having tutored reggae icon Bob Marley and many others in the faith of Rastafari which was to emerge as a new world religion and way of life out of Jamaica. Planno, an outstanding panAfrican scholar and activist, travelled to the United States of America, Canada, the United Kingdom and some fifteen African states, lecturing on the Movement developed in Jamaica, celebrating the Emperor of Ethiopia, Haile Selassie I as God incarnate. For more than fifty years, this elder was seen as the de facto leader of the Rastafari movement of Kingston. The study applies Paulo Freire's theory of a 'pedagogy of liberation' to assess whether Rastafari thinkers such as Planno can be seen as facilitating a trans-Atlantic conscientisation towards remedial African national development and liberation from what Garvey (1927) described as 'mental slavery'.
\end{abstract}

\section{Résumé}

Cet article vise à élargir la notion de la sphère publique africaine pour inclure la diaspora historique à travers une mise en évidence des travaux de Mortimo Planno, historien de la culture, sommité et plénipotentiaire rastafari, en comblant le vide entre l'Afrique et sa diaspora, par l'examen de la définition par Planno de la sphère publique africaine, comme exprimée dans la plupart de ses écrits, et le texte principal, « The Earth

* Institute of Caribbean Studies, Faculty of Humanities \& Education, University of the West Indies, Mona Campus, Jamaica. Email: bongoniah@yahoo.com 
Most Strangest Man », ainsi que ses récits de voyage exprimant son discours sur le Retour en Afrique. Mortimo Planno aurait formé l'icône de reggae, Bob Marley, et bien d'autres dans la foi rastafari qui devait émerger comme une nouvelle religion mondiale et un mode de vie à partir de la Jamaïque. Planno, un remarquable intellectual et militant panafricain, s'est rendu aux États-Unis d'Amérique, au Canada, au Royaume-Uni et dans une quinzaine d'États africains, pour animer des conférences sur le mouvement développé en Jamaïque, glorifiant l'Empereur d'Ethiopie, Hailé Sélassié I, comme Dieu incarnée. Pendant plus de cinquante ans, cet homme était considéré comme le leader de facto du mouvement rastafari de Kingston. Cette étude applique la théorie de Paulo Freire d'une " pédagogie de la libération » pour évaluer si les penseurs rastafari comme Planno peuvent être considérés comme ayant facilité une conscientisation transatlantique en vue de soutenir le développement national en Afrique et la libération de ce Garvey (1927) qualifiait d'« esclavage mental ».

\section{Prologue}

Zimbabwe

Every man got a right to decide his own destiny

And in this judgement there is no partiality

So arm in arm with arms we'll fight this little struggle

'Cause that's the only way we can overcome our little trouble

Brother you're right. You're right. You're right. You're right

You're so right

We go fight (We go fight)

We'll have to fight (We go fight)

We're gonna fight (We go fight)

Fight for our rights

Natty dread it in a Zimbabwe

Set it up in Zimbabwe

Mash it up in a Zimbabwe

Africans a liberate Zimbabwe

No more internal power struggle

We come together to overcome the little trouble

Soon we'll find out who is the revolutionary

'Cause I don't want my people to be contrary

Chorus...

Divide and rule could only tear us apart

In every man's chest there beats a heart

So soon we'll find out who is the real revolutionaries

And I don't want my people to be tricked by mercenaries 
Brother you're right. You're right. You're right. You're right

You're so right

We'll have to fight (We go fight)

We're gonna fight (We go fight)

We'll have to fight (We go fight)

Fighting for our rights

Natty trash it in a Zimbabwe

Mash it up in a Zimbabwe

Set it up in a Zimbabwe

Africans a liberate Zimbabwe

Africans a liberate Zimbabwe

Natty dub it in a Zimbabwe

Set it up in Zimbabwe

Africans a liberate Zimbabwe.

Bob Marley (1979), Zimbabwe

\section{Foreground: The Carry Beyond Geo-sphere, A Map of the World}

Our magnificence dominates the Three Indias, and extends to Farther India, where the body of St. Thomas the Apostle rests ... Seventy-two provinces obey us, a few of which are Christian provinces; and each its own king. And all their kings are our tributaries ... .If you can count the stars of the sky and the sands of the sea, you will be able to judge thereby the vastness of our realm and our power (Extract from a twelfth century letter authored by Prester John, reproduced in Silverberg, 1972, pp. 42-45).

Long before, there was the Treaty of Tordesillas of 1494, dividing the world (not so neatly) between Spain and Portugal, an Ethiopian sovereign was to have circulated word of his realm and extensive Empire. In 1165, Manuel the Emperor of Byzantium, the Emperor of the Romans received letters from one Presbyter John (also Prester John or Priest King), a Christian Emperor and King of Kings who was a direct descendant of the magi mentioned in the Gospel (that visited and presented gifts to the Christ child). The letter indicated a domain constituting a tribute empire that spanned the globe beyond the boundaries then known to the European world, expanding east and west of the uttermost end of the earth. Though significantly altered through various translations and interpolations, the letter clearly indicated the Presbyter John as unsurpassed by any other in power and wealth. The letter created such a stir in Europe that for the next five centuries, various attempts were made to establish the identity and specific location of this legendary emperor as well as to behold the wealth and command he was reputed to have over these territories and their peoples. This letter and its author - though originally at 
times confused with Genghis Khan ${ }^{1}$ - is now generally accepted to relate to the Ethiopian Sovereign and his empire, believed to have extended to Africa, Asia and into the Americas. This letter, though the subject of much debate and scepticism, provides yet another source to triangulate the theories of a pre-Columbian African presence in Central and South America as well as in South Asia, Polynesia and beyond, chronicled in the oral histories as well as in Chinese records of the twelfth century (Van Sertima 1975). It took Christopher Columbus's voyage in 1492 to the Americas for Europeans to secure further evidence of the expansiveness and wealth, literally the 'other worlds' across the seas and the wealth that could be possessed by adventurers into these waters yet unknown by their explorers. This 'discovery' set in motion one of the most ambitious projects ever embarked on by mankind, to conquer the world for Christendom, the latter perhaps a euphemism for establishing and justifying the European hegemonic dominance that subsequently developed. Various strategies were put in place to facilitate that project, the chief instrument for this mission being the Spanish code known as the Requisition, which legitimated not only the conquest of the "new world' by Spain on behalf of the Pope, but also the parcelling off or allocation of virtually most of the western hemisphere to the Spanish State (see Wynter 1995:19).

Sylvia Wynter (1995) reminds us that not all the 'natives' of the Americas were silenced in their opinion of Christopher Columbus and the project of European capture of most of the 'New World':

[T] he Pope being the Lord of all the universe in the place of God, and he had given the lands of the Indies to the King of Castile, the Pope must have been drunk when he did it, for he gave what was not his ... The King who asked for and received this gift must have been some madman for he asked to have given to him that which belonged to others. - [The Cenu Indian's reply to the Spaniard 'local culture' conception of the legitimacy of the Papal Bull of 1492 as one which 'gave' the New World to Spain. Quoted in Wynter 1995:18.]

Wynter picks up, where the Cenu Indian left off, to extrapolate:

Equally, the discourse of the Requisition, like the correlated discourses which legitimated the West's global expansion, was only true within the terms of the 16th century variant of the matrix Judea-Christian culture of the West, and therefore within the terms of its behavior-motivational belief system and neo-Augustinian principle of explanation (1995:20).

Hickling (2004) through his methodology of psycho-historiography supports Wynter's argument and identifies the foundational ethos and inner logic of the Columbian American Colonial project on 'delusional psychology' founded in greed (Hickling 2004:54). This delusion led to the establishment of European 
outposts in the geo-sphere which came to be known as the Caribbean, a name derived from a 'cannibal' Amerindian tribe that Columbus called 'Caribs' (a corruption of 'Galibi' meaning 'brave men'), that occupied most of these islands which form an arc linking North and South America. Within one century of Columbus's voyage, there was to unfold major international battles that claimed every scrap of rock dotting the area of the Caribbean involving peoples from every corner of the world, for the then dominant powers in Europe. Within two centuries of Columbus's arrival, the emergent island outposts were appropriately labelled with European national flags, while miniscule numbers of local administrators maintained extractive links on behalf of these 'mother countries', who were now being afforded abundant riches to fuel an ambition to develop their citizenry. The activities in the Caribbean had provided not only economic wealth but had aided intellectually and philosophically, expanding research and closing knowledge gaps. It also helped significantly to develop and expand the range of language-driven skills required to administer the region in absentia, as well as their general interpretations of laws and codes, and social structures and relations derived from administering extractive networks constructed to drive European advancement. For this global network to succeed, the African majority responsible for most of the labour had to be convincingly contained, controlled and incorporated into a delusional construct through legislations and a penal system which shackled impulses to resist. Resistance still could not be totally contained as Wynter (1977 \& 1995) notes, and was even prolific in islands such as Jamaica and Haiti; the latter by way of the now famous Haitian Revolution of 1791 which ended France's control of that territory almost two hundred years prior to decolonization commenced in the rest of the region (between 1962 and 1981). To the extent that the Caribbean experience has been one of African political disempowerment, Rastafari have often rendered the word 'Caribbean' as 'carry' 'beyond', to speak to the cleavage of the peoples away from African shores and their imprisonment in tiny islands far across the seas. Carry beyond is also understood and applied poetically to speak to a state of darkness and ignorance caused for lack of culture and self knowledge to exist only in a state of perpetual slavery.

The legacy and space that the Carry Beyond occupies is therefore one of strong ties with all of the dominant European countries and to some extent with Asia, the home countries of the indentured and merchant classes, but very weak and undervalued links with Africa, the majority of the labouring population's homeland. In the British West Indies, colonialism tried to ensure that there was no link between the African continent and the Caribbean that was not an extractive one, and so there was to be no reverse flow of population or investment towards Africa - that is no direct connections that would 
strengthen the African connection. Africa represented labour, the West Indies represented land under European control into which many Africans were imported to work, and for so many others it could be said, and put to death. Rodney (1973) details how Europe for the past four centuries manipulated African wealth to under-develop the continent. This 'underdevelopment' was transplanted to the islands by the designation of 'slave' or the legal nonstatus of the African, a dominant but impotent majority. In Jamaica, Mortimo Planno, Rastafari Elder and teacher identifies (within a population pyramid headed by minorities and expanding downwards) an African society that is under denial and suppression. Planno therefore locates Jamaican and by extension the Carry Beyond as constituting the following hierarchy: 'Jews, Arawaks, Mulattos, Arabs, Indians, Chinese and Africans - all of which spells JAMAICA' (see Planno 1996). Planno's acrostic scheme for Jamaica recognizes that the core, base, backbone, substantive body of Jamaica is always built and driven by an estranged African element constituting more than ninety per cent of the population ${ }^{2}$ but which remains silenced and unrepresented in many levels of the official society in ways not dissimilar to the earliest days of colonization when overt racism allowed unabated violence and hardship to be inflicted on the enslaved. Since Africa never achieved political hegemony within the Caribbean, at least not in the conventionally recorded histories, ${ }^{3}$ her peoples seemingly have been negatively affected by it, and the African global family has thus suffered an irreparable disadvantage. Indeed, if the realm of the Presbyter John of the twelfth century boasted that '.. there is no strife among us; our people have an abundance of wealth ... There are no liars among us', ${ }^{4}$ by the time of the European Christian stewardship, the wealth, population and existence of these Indies (East and West) were effectively crippled and transferred away from these spaces, their populations diminished in wealth and dignity.

\section{The African Sphere}

Think about it: everyone they tried to work those fields in the hot sun dropped like flies and then they started bringing us over from Africa. It didn't matter how many of us died as long as we lasted through a crop, because they figured on an endless supply (Greenlee, S. 1969:114-115).

The Africans on the west side of the Atlantic owe a debt to Marcus Garvey who contributed hugely to the groundwork of teaching the people about their race and its experiences. Decades before Garvey, Alexander Bedward had emerged in Kingston, Jamaica, with a racialised message about the emergence of a free African population, no longer subject to white colonial authority. Within the first three or four decades of the twentieth century, not 
only was there street activism teaching of Africa (see Elkin 1972), there were also a number of published works relating to the same racialised excavations. Athyli Rogers, Fitz Ballintine Pettersberg, Leonard Howell, Amy Jacques Garvey, and J.A. Rogers worked toward an elevation of the population for an understanding of the truth of Africa. This therefore means that by the 1940s, developed cadres emerged in the Diaspora teaching Africa from religious, political and academic viewpoints, with the Rastafari as one of the latest in that trajectory of teachers. Planno introduces his research on the African sphere in his book The Earth Most Strangest Man: The Rastafarian, as follows:

Ethiopia the Aincient (sic) Kingdom of Africa has made an unnoticed expansion of the Ethiopian Kingdom. From one end of the Earth to the other. Africa being inhabited by invading European Nations Has lost most of her written history to the invaders, who in turn copy and then destroy the original (Planno 1996:3).

Immediately as we are told that the Ethiopian Empire expanded the earth, Planno goes on to outline that due to invading Europeans destroying our sources, Africans have been at the mercy of second-hand copies of their history. Among the Rastafari the term 'Ethiopia' is still often used in its original sense, the Greek description of the African landmass, occupied by 'sun burnt' peoples. Mortimo Planno further explains the Rastafarian position:

By Ethiopia I and I mean one continent, by Ethiopia I and I mean the Country Ethiopia with its capital Addis Ababa. By Ethiopia I and I mean All for One, One for all operating in this manner there can be no failure. The only true interpretation for Africa for the Africans. I and I being in captivity Has to admit, to names of those who did pass through great tribulations (Planno 1996:3).

Planno conforms to the traditional Rastafari definition of Ethiopia, but he also expands his meaning to include the historical trajectory of experiences of the African people - from the continent en masse, to the country of the Ethiopian highlands, to the captive Ethiopians beyond the shores of Africa. For this third category of Ethiopians, those who fell into captivity (and who were given Anglo-Christian names), although they are numerically and culturally dominant within their captive 'carry beyond' nations, these societies are still conceived as European satellites or outposts. This is where the work of Rastafari has been most critical in transforming the mindset of populations of these outposts to reflect the needs of the African majority as a way of helping to liberate our minds - according to Bob Marley one of our great challenges. This paper makes a case for Rastafari to be construed as an African Diasporan teacher fashioned in a pedagogical 'sphere' emerging out 
of a dominant Ethiopianist and Pan-Africanist identity, deeply embedded in the diaspora. To some extent, it may be said that Ethiopianism has expressed itself as a far more active and perhaps even 'militant' force among African Diasporans, especially after the coronation of His Imperial Majesty Emperor Haile Selassie I. ${ }^{5}$ This was further deepened and strengthened when Italy invaded Ethiopia in 1935, an episode that was to capture the attention of many African Diasporan 'pariah' intellectuals, for whom media coverage of Africa was received eagerly. Most West Indian scholars and thinkers at the time were focused on North America and Europe. ${ }^{6}$ The Movement of Rastafari thus came into being at a moment when Ethiopia had opened a way for attention towards the African continent in general. This Rastafari sphere, I argue, is indispensable to an ongoing liberation conceptualization and deployment internationally, and significantly contributes to the broadening and strengthening of the African Public Sphere.

The importation of Africans and the system of slavery ended formally in most of the Americas by the close of the nineteenth century. Within a generation of the 1834 British West Indian Emancipation Act, the Africans inhabiting the region had called into question their lack of social and political status. Although legally free, it took another century after Emancipation for Africans to achieve a political voice. In 1933, five years after Marcus Garvey was deported from the United States after being imprisoned there, the Rastafari founding patriarch Leonard Howell, who was also deported from the United States, emerged in Jamaica. He preached a similar message to that of the Cenu Indian, while echoing sentiments close to that of the Presbyter John's letter, some five centuries after Columbus's design took root in the Americas. Howell preached to the people gathered in the marketplace and in the public sidewalk street assemblies ${ }^{7}$ a message of rejection of Western hegemony and the celebration of an Ethiopianist trajectory emergent through the legendary Solomonic King who had just been crowned. Within a decade of Howell's activism preaching the Messianic interpretation of the 1930 coronation of the Ethiopian sovereign as the harbinger of Africa's redemption, a Movement was to develop in Kingston, Jamaica, which quickly spread nationally and internationally to emerge as an important voice and discursive public tradition for the Conscientisation of Africans at home and abroad.

I now seek to concretely identify the African sphere, by way of an engagement with the cosmological outlook developed by the Rastafari of Jamaica, and particularly as identified by one of the Movement's first and most long serving plenipotentiaries and teachers, Mortimo Planno. Rastafari in this paper is defined as an Ethiopianist-centred worldview and Movement, venerating the life and character of Emperor Haile Selassie I of Ethiopia as 
the prophesied Redeemer King of Creation. Rastafari can also be defined as the principal teacher of liberation - or as Howell designated himself, teacher of 'famed wisdom'. ${ }^{8}$ From these two definitions emerges an argument for the Rastafari as a teacher of an African liberation worldview. This places the Rastafari as a quintessential force in incubating progress among marginalized Afro-centric ${ }^{9}$ brothers and sisters globally. This point also helps to define Rastafari as a Pan-African diasporic medium especially in the light of the universality of the conditions that Africans have suffered. Boyce Davies affords an appropriate summation of the African condition:

For many years the status of African Diaspora peoples in various nationstates has entailed as recognition that they are always a 'deportable subject'. ${ }^{10}$ Additionally, Africans often did not have access to the basic rights accorded citizens in many locations prior to civil rights and other anti-colonial movements. The ongoing denial of rights speaks most strongly to what the concept of 'citizenship' in the United States [and the Americas] has meant for black people. As a direct result, this sense of statelessness can have the effect of creating not only a sense of alienation from the nation-state but also an international African identity in the diaspora (Boyce Davies \& M'Bow, 2007:19, my emphasis).

The notion of a 'deportable subject' coupled with the idea of 'an international African identity in the diaspora', provides me with an entry point for a more poignant introduction of the inner logic, role and place of the Rastafari Movement within the African diaspora. Whereas it took just the label of 'slave' to transform an African into a subhuman, it has taken almost two centuries of extreme violence and bloodshed to begin to reverse the scars of the slave legacy from the population so affected. Boyce Davies et al. further highlight the fact that the African in the West has had even today to mediate the societies of their birth from the position of 'denial of citizenship rights (Constitutional rights)...' These authors further highlight the fact that in the cases where citizenship or constitutional rights are secured, arbitrary arrest and imprisonment become loop-holes within the state apparatus to deny citizenship. In the African American context, this has been best demonstrated by the over-representation of black males in the prisons, disproportionate numbers in the frontline armed services, high mortality in confrontations with civil law enforcement, and consequently high numbers in the penal institutions (especially among males under thirty-five years of age). ${ }^{11}$

The African public sphere cannot therefore only be a continental enclosure ${ }^{12}$ but must also facilitate significant populations of Africans abroad, whose histories, circumstances and consciousness unify them with those Africans at home. Marcus Garvey recognized that there was a need for a 
global African consciousness, dialogue and networking, and through the Universal Negro Improvement Association (UNIA) this objective was being advanced. Unfortunately however, the organization was unable to evolve and grow after the demise of Garvey, its chief architect. The Rastafari which followed Garveyism was well poised to expand the reach of Garvey largely due to its religio-political framework, which connected to the combined pedagogical needs of religious rearmament and political activism, being a modernizing syncretic fusion. Rastafari movement through a diasporan bricolage of Ethiopianism, Pan-Africanism, Garveyism, Hinduism as well as Christian eschatology has developed a system of reasoning, with an impressive international resonance, and has moved towards the development of a liberatory praxis which would see improvement for the African citizenry internationally. I would further note that, the Movement operates more like a counter public sphere where, through an insidious and discursive process of reasoning, provides the basis for teaching a common culture or assist in framing, the icons, images, symbols, mores and general way of being that ultimately inform 'an international African identity in the diaspora'. My argument now turns more specifically to the Rastafari definition of the African Sphere, and more specifically the African Public Sphere, as seen and impacted through the works and ideas of Mortimo Planno.

\section{Basis of Wisdom: Mortimo Planno's Open Yard}

We are volunteer Ethiopians

Agitating for our Rights

And We'll never stop fight

Until we brake (sic) down Babylon Wall. (Planno 1996:7)

The impact we [Rastafarians] have is that of a pressure group who have forced certain pressures on the establishment ... that they have to give African countries recognition and move towards having better relation with African countries. (Planno 1979)

Mortimo Planno was born in Cuba in 1929 to May Parker, a Jamaican, and Miguel Planno a Cuban tobacconist. In the early 1930s, Planno's parents moved to Jamaica and he recalls that by the time of the outbreak of the Second World War in 1939, when he was ten, he had developed and begun to articulate a strict anti-colonial consciousness which saw him siding with the Germans against the British colonial overlords. By the age of 30, Planno was a known community leader and activist whom the University of the West Indies would consult with in studying and recommending that the Rastafari be considered a legitimate movement in pursuit of achievable goals and that the government be of assistance (see Smith et al. 1960). Planno was 
a Rastafari leader who was given to writing letters, many of which he directed to the 'Powers and Principalities', in pursuit of justice for the disenfranchised and the poor and in particular the Rastafari struggles within contemporary society. The 1960 Report was generated from one such Planno letter, resulting in the dispatch of a fact finding Mission to Africa (April 1961) to access the willingness of Ethiopia, Ghana, Liberia, Sierra Leone and Nigeria to receive the Jamaican Rastafari and the larger Back-to-Africa interest group. Planno was placed on the Mission as a leading representative of the Rastafari community. The Mission first had audience with the Ethiopian Emperor Haile Selassie I in Addis Ababa, who assured them that Ethiopia could accommodate all the Africans from the West Indies who desired to return (see Planno et al. 1961). After Ethiopia, the Mission was received in Nigeria by the Governor General, Nnamdi Azikiwe; later in Ghana, Liberia and Sierra Leone, the delegates were received respectively by Kwame Nkrumah, William Tubman and Milton Margai (see Planno et al. 1961). Though there were no specific promises of repatriation, the Mission transmitted to the Rastafari a sense of action as well hope that was only halted when the national government changed and the agenda of 'migration' to Africa (as it was described) became a casualty of the new administration's focus (see Planno 1996 \& Nettleford 1972).

After Planno's return from the Mission to Africa he became more legitimately seen as the leading Rastafari among a largely unorganized cadre of disaffected urban dwellers. Planno mounted public protests, held street meetings, kept concerts and theatrical performances - all geared at animating the consciousness and 'overstanding' ${ }^{13}$ of Africa. Planno even introduced the teaching of Amharic in Trench Town, Kingston. Additionally, he became one of the first internationally acknowledged spokespersons for the Movement and toured the United States, the United Kingdom and Canada, representing Back-to-Africa to the West Indian Diasporas. After the Emperor's visit to Jamaica in 1966, his position was affirmed further as a significant Rastafari leader, the one who saved the day when the machineries of state protocol failed, being unable to contain the tens of thousands who had come to see this truly legendary ruler. The flaming torches, the palm branch-bearers, drum players; spectators - who had all come to hail their King of Kings thronged the plane on the tarmac. It took the Emperor's intervention by way of his request that Planno be called upon to settle the multitudes and allow for his deplaning. Eyewitnesses generally agree that the scene was extremely tense. Onlookers imagined total disaster with fire, explosions and stampedes, and an impending national disgrace and international disaster. The stage was set for Planno's skills to be exercised. Planno - not a part of the official 
welcome party - had to be summoned by loudspeaker. After a brief salutation to the Emperor, he proceeded to restore calm. In the words of a witness, Brother Dyer, an elder whom Planno inspired into the faith of Rastafari and who later walked to Ethiopia from Spain, 'Planno opened his mouth and began to teach them about their history'. Planno recalls starting with the Psalm that he believed he was seeing - unfolding before him at that time and he spoke thus:

Why do the heathen rage, and the people imagine a vain thing? The kings of the earth set themselves and the rulers take counsel together, against the lord, and against his anointed, saying, let us break their bands asunder, and cast away their cords from us. He that sitteth in the heavens shall laugh... (Psalm 2: 1-4).

Planno's ability to avert disaster due to the failure of protocol saved the day and prevented international embarrassment. He earned the title of 'Prime Minister for the day ${ }^{14}$ in the local newspaper. The arrival of the Emperor had been dreamt of and desired ever since the doctrine emerged in the 1930s. For those three days, Jamaica had become Ethiopia according to Planno's analysis, as the Emperor's reception by the people was to be matched only by the love and enthusiasm shown him by Ethiopian nationals. The visit vindicated the Rastafari faith, while intensifying the desire for Ethiopia. After this moment in Jamaican history, accounted as the most memorable state visit, ${ }^{15}$ Planno became a magnet for the West Kingston community (the Rastafari in particular) until his residence became established as one of the first prominent inner-city (Trench Town) sites for creative discussions. Individuals began to converge on Planno's eighteenth fifth Open Yard as he called it — to 'reason' and solidify critical opinions. Planno's space perhaps operated as an alternative (that was African centre) dialogical public sphere within the margins of the society. To this extent, Planno's Open Yard perhaps operated more as a 'counter-public' sphere. Its agenda was subversive, particularly that aspect which looked outwards to Africa - as Africa was still remote with respect to the national agenda and well outside of the public sphere's concerns. ${ }^{16}$ Within Planno's sphere, there was an outstanding appeal, among Rastafari brethren: musicians, jugglers (informally employed), sporting personalities, academics, artistes and other individuals converging on Planno's space to share in the reasoning. He explained the method as such:

[A]s we get the opportunity we use it, use it fi carry one foot forward. Every time an opportunity open the door we go through that door and call down Africa pon dem. Marcus Garvey learn from Mohammed Ali that the people of the Caribbean want to learn more about Africa. And him Marcus Garvey did not have the language to tell it to the people. Him didn't really have that 
approach. The Rastaman for instance have a better approach than him in telling the people about back-to-Africa ... to explain to you who can't read what British write - how 'you going to suffer through your own desire' (Planno 1998).

Planno provides an indirect critique of Garvey's 'bourgeois' strategies for conscientising and developing an African sphere within the Diaspora by highlighting the state of being of the mass of the populace at the time of Garvey's UNIA. Further, Planno suggests that the 'Rastaman' become the translator of Garveyism to these masses, many of whom were illiterate. In his lecture, 'Polite Violence' Planno helps to bridge the gap between the contribution of Marcus Garvey and that of the Movement of Rastafari. Though emerging from the early 1930s, it was only in the post-second world war period that the Rastafari movement started to lobby explicitly for the official authorities to engage Africa as a real and actual part of the majority of the population's culture and way of life. With the emergence of a West Indian university located at Mona in Jamaica (in 1948), the newly formed United Nations forum for the expression of international disputes, and the widespread decolonization discussions, Back-to-Africa as a pathway for some of the society was also seeking some representation. Garvey's work had slowed after the 1930s, and more so after his passing: the Rastafari movement stepped into this void to 'tell the people about Back-to-Africa'. Planno even composed songs to provide his audiences with instructions. He started and ended his gathering with such singing, 'Tell out King Rasta doctrine around the whole world...'

Capitalizing on the doctrine of Ethiopianism as seen through the religious and later intellectual movement of the early to mid-nineteenth century, Rastafari by the 1950s had developed a grassroots version of this ideology and had given it a religio-political flavour, this religious fervour, arguably a less evident element of Garveyism. Philosophically, this component added to the basic Back-to-Africa framework of self-reliance, a spiritual anchor through the focus on the Emperor and Ethiopia. Ethiopia's primacy within Rastafari owed not only to its long un-colonised history but also based on its international profile since the battle of Adwa in 1896, when a decisive victory over the Italian invaders unleashed a renewed hope in the African ability to overcome seemingly ubiquitous oppression. With the international prominence of the Emperor Haile Selassie I, after his coronation as well as the Italo-Ethiopian war (1935-1941), there was no absence of active discussion and scrutiny of this region by Africans everywhere. In Jamaica, at the outbreak of the war, there was a large protest meeting in Kingston at which some 1,400 Jamaicans signed a petition asking the British Crown to grant permission for Jamaicans 
to enlist in the Ethiopian Army. ${ }^{17}$ The war in Ethiopia also strengthened the chiliastic readings that the Movement placed on that country as manifesting the Revelations: the final battle with the beast, (representing/repeating the story of the Romans with Christ, now the Italians through Mussolini, sanctioned by the Pope, the anti-Christ), which was trying to destroy the Messiah, Emperor Haile Selassie I. ${ }^{18}$ Leonard Howell, in his first message at the inception of the Movement, advised the people to turn their attention to the newly crowned Black Emperor and study his laws and constitution, as he was their true redeemer, not the white British King. The appearance of the Ethiopian Emperor on the throne became that moment of truth fulfilling the promise of the Messiah. Howell, like Planno, did not expect to have this interpretation delivered by anyone from 'official' society - an official society that the Rastafari soothsayers were to later represent as 'Babylon' or 'the system', as false preachers and teachers.

The activism that the Movement embarked on resulted in a shoring up of the knowledge of and desire for Africa within the population in general which at that time had very little true awareness of the continent. Africa was affirmed, studied and monitored. The news of Africa in the press was re-interpreted by Rastas. For example, though reported as a problem in Kenya, the Rastafari immediately identified with the struggle of the Mau Mau in the 1950s and by some accounts were inspired by this group to develop the aesthetic of dreadlocks (see Chevannes 1998). The period of decolonization became infused with discussion of the restoration of linkages with Africa through 'repatriation' (or migration) of Back-to-Africa advocates. The decade between 1958 and 1968 therefore saw a groundswell of the idea of Back-to-Africa in Jamaica through the work of the Rastafari, who by this time had begun to organize different associations that looked at the best ways of manifesting Africa. In 1958, as a result of the first international Rastafari convention called in Back-o-Wall, Kingston, a telegram was sent to Queen Elizabeth II stating, 'We the descendants of Ancient Ethiopia call upon you for our repatriation...' Several months later the Rastafari camp in Back-o-Wall was destroyed by police and its leader arrested and imprisoned. The convention, or 'Grounation', as it was called, was held on the anniversary of the Ethiopian victory at the Battle of Adwoa (March 1, 1896). It lasted twenty-one days and had the desired effect of making the Rastafari (within the British Commonwealth) visible as an organization of African and Back-to-Africa minded members of the society. The wider society felt intimidated by the brethren and relations deteriorated between the Government and the public towards the Rastafari movement (van Dijk 1993:117-118).

After this Grounation in Kingston, the Rastafari became a far more articulate and visible anomaly in society. The cultivation of dreadlocks became 
widespread as initiates became part of an embodied identity, and used the body as a site of resistance. This feature has been present from the outset and over the years has been elaborated further. The embrace of the Ethiopian national colours has also been a part of this signification, as is the cultivation of merely a beard, sometimes instead of dreadlocks. The display of pins and buttons with the Ethiopian sovereigns, Ghanaian flag, as well as Marcus Garvey and colours of the UNIA also feature in this embodied practice. As a result of the Rastafari critique of the wider society, symbolized by this visual presentation, the Movement became what Planno describes as a 'fascination for the society, journalists ... tourists' ${ }^{19}$ Coupled with a doctrine that focused on 'the dark continent of Africa', the strange, anachronistic ideas of the Rastafari became a regular part of the media's obsession, until eventually the print media also became an outlet for the 'truth about the Movement to be revealed'. For example, on the issue of the Rastafari right to hold the philosophy of Ethiopia, Planno wrote in a letter to the Editor of The Daily Gleaner quoting the UN Declaration on Human Rights:

Mr. Editor, under article 15 (1) Everyone has the right to a nationality, (11) No one shall be arbitrarily deprived [of] his nationality nor denied the right to change his nationality... The Rastafarian Movement made representation to government for a nationality change. To many people the Rastas are making trouble, when they ask for a nationality change... Daily Gleaner, December 19, 1963:12).

Planno's Back-to-Africa advocacy for the Rasta brethren kept Africa alive generally, with his clamouring for repatriation. The discussions being promoted became interpreted by the wider society as a need for greater understanding of Africa. Roy Augier, one of the authors of the now famous Report on the Rastafari Movement in Kingston indicated that the Rastafari phenomenon created a space for the insertion of the study of Africa within the curriculum as well as the placement of African pre-Columbian history within the University of the West Indies curriculum and that of the secondary school system. Walter Rodney, according to Augier, was handpicked to provide this contribution to the University (personal communication, June 2008). The obsession of the Rastafari with 'the unresolved legacy of colonialism' had helped to remind the wider society that its major cosmological and demographic locus was Africa and assisted in legitimating the claim of the African presence in Jamaica and the West Indies (hitherto denied). This coincided with the period of 'Black Power'. However, its expression in Jamaica occurred most clearly through the engagement of Rastafari with Africa. Throughout the remainder of the 1960s, especially after the visit of the Emperor in 1966, various attempts were made to pursue repatriation, 
including the attempts of Planno's Rastafari Movement Association to fund the repatriation of nine families to Ethiopia. When it became apparent that the efforts were not yielding appropriate rewards, largely due to lack of financing, reggae became the chief source of engagement for the next generation of Rastafari activism through conscious reggae and other means. This atmosphere which was to partially emerge from Planno's Open Yard in Trench Town became the point of convergence for radical university students and researchers, musicians, athletes and Rastafari brothers and sisters.

Between the end of the 1960s and the death of Bob Marley in 1981, just over a decade, the Rastafari of Jamaica developed a medium to speak to the world, proselytize its new faith and elevate the discussion of Africa everywhere. This medium or media was reggae music - defined by some as the King's (Ethiopian Emperor's) music. From its inception, reggae was associated with the Rastafari movement and it is perhaps not surprising that it was easily imbued with the sentiments of the Movement's doctrine and vision. Rastafari's Ethiopianism became more embedded in the music which included sentiments of repatriation, but also expressed solidarity with suffering Africans, not only in Jamaica but also on the continent of Africa. Artists also chose to use African names, African chants, themes, clothing and ritual practices within their creative works as a part of the reclamation of the human self and continent they had lost.

\section{Rastafari: Building African 'consciousness', Remapping the Earth}

A people without a nation that they can really call their own is a people without a soul. Africa is our nation and is in spiritual and physical bondage because her leaders are turning to outside forces for solutions to African problems when everything Africa needs is within her. When African righteous people come together the world will come together. This is our divine destiny. - HIM Emperor Haile Selassie I of Ethiopia.

Bob Marley received a formal invitation to attend the independence ceremonies of the new nation of Zimbabwe on April 17, 1980. The previous year, when Marley first publicly performed the song 'Zimbabwe' in Boston at the now famous Amandla concert (so-called for the phrase 'Amandla Ngawetu', 'Power to the People'), where his performance raised a quarter of a million US dollars ${ }^{20}$ for African liberation, he paused during the performance and made the following speech:

The Third World struggling ... and we must come together for Zimbabwe ... Women and children shall fight this revolution ... we can be free, we want go home to we yard ... Rastafari know that ... Don't let propaganda lead you astray, false rumors and false propaganda. Haile Selassie I the Almighty!! ... 
Zimbabwe must be free by 1983, Jah seh, Africa must be free ... So everyone have a right to decide his own destiny ... Put your feet in the dust ....A people without knowledge of their past is no better than a tree without roots... We smoke herb so we get one meditation, and they don't wan' fe see us in unity, C'mon children!! Yeah!!!. I couldn't mek a speech, I could mek a speech, but I'm gonna tell ya that I' $m$ gonna fight for my rights. I'm a Rasta man and we are Rasta people. Consciousness cover the earth ... Hey sisters!! Awake from your sleepless slumber, emancipate yourself from mental slavery, none but ourselves can free our mind, yunno what I'm saying? Babylon burning!! Its vibration mek the whole world stop. Burning!! No more force. A free the people!! Yunno something? We're gonna do it ... with a nuclear bomb! Wake up and live! Rastafari, the Almighty God!! With no apology!! ... o, it's time for us to be free!!! (Davis 2006:215).

Planno, regarded as Marley's tutor-mentor, describes Bob Marley as akin to a Rastafari Bishop, given his power and authority to move across the world as a chief emissary of the faith (see Planno 1998). Through the music which he used as a teaching tool, Marley expounded the philosophies of the ages that he had come to know through the consciousness of the Rastafari. Marley's method was infused by his abilities as a 'total' performer. He often appeared as though in trance, transporting his audiences to a higher consciousness through rhythm and thought-provoking verses. Davis (1984) viewed them as a crucial force in a liberatory praxis 'toward human unity and dignity' (p. 216). Planno's and Davis's assessments of Marley help to place the artist within a framework more akin to a 'theological' worker, and Marley's own testimony of faith in the Ethiopian Emperor Haile Selassie and the Rastafari movement help to support this claim.

Applying Freire (2000), one can contextualize the role of the Rastafari within the African sphere, and in particular within the Diaspora. Freire examined the importance of dialogue in the process of human consciousnessbuilding and recognized that there is no 'true word' that is not at the same time a praxis. He further indicates that 'to speak a true word is to transform the world' (2000:87). Emerging from its word-based philosophy of a redeemer King, Rastafarians developed a praxis to transform the world. For this transformation of the world to occur, 'spirit media'"21 like Marley are able to achieve a genuine dialogue within his works which convinces his audience of his (divine) inspiration as well as their own ability to command the same. Freire argues, however, that dialogue cannot exist if there is no profound sense of 'love' for the world and for people.

Love is at the same time the foundation of dialogue and dialogue itself. It is thus necessarily the task of responsible subjects and cannot exist in a relation of domination. Domination reveals the pathology of love: sadism in the 
dominator and masochism in the dominated. Because love is an act of courage, not fear, love is commitment to others. No matter where the oppressed are found, the act of love is commitment to their cause - the cause of liberation. And this commitment, because it is loving, is dialogical. - Freire 2000, p. 89.

Through the dialogical process of 'reasoning', Rastafari evolved a cogent philosophy and interpretation of the African Diasporan experience: according to Planno (personal communication, 2002), 'we get the people more wise'. The principles of the public reasonings were taken into the studios of Kingston by the Rasta brethrens and the result was a new music genre and a new breed of teachers on the Pan-African situation. Bob Marley was to emerge by the early 1970s as a leading exponent of this purposeful sound. Reggae music, as this sound has come to be known, has been defined by Rastafari as 'the King's music', and to a great extent the contents and overarching concerns of the genre have come to embody the African reality and ambition. By 1980, approximately a decade after his international debut, Bob Marley had become the most famous Pan-African anti-colonial champion, in a truly revolutionary and uplifting way, so much so that he had made a significant impression on the various liberation movements in Africa, and Southern Africa in particular (see Campbell 2007).

\section{Summary and Conclusions}

What is therefore this new map of Africa? How is it to be envisioned, harnessed and administered? Africa has perhaps suffered from a diminution in its political scope and geographical range by not engaging in a philosophy of hegemonic dominance or an explicitly imperialist worldview. Despite this, her peoples have become a key Diasporan phenomenon, numerically large and exercising potent cultural influence internationally. Within this constituency, the Rastafari have emerged on a mission of conscientisation for the masses about the need for progress and liberation. Through the veil of Ethiopianism, the Rastafari have historicized the African diasporan experience from a perspective that has critiqued the overarching paradigm and provided the tool for its transformation. To this extent, the Rastafari have fashioned and upheld and continued to administer an African sphere that has allowed for the development of a citizen of Africa, a Pan-African community, existing at the level of a transnational being. This feature of the Rastafari has been fashioned and developed over the years by successive generations of elders of the faith, from Howell to Planno to Bob Marley and beyond. It is generally misunderstood and undervalued - nonetheless in spite of this, it has found resonance among oppressed peoples universally. To this extent, the Rastafari have helped to create Africa abroad, and deepen its significance, particularly 
for many of those who were transplanted, stateless and homeless - plucked from their homeland under duress and great pain. This new map of Africa is therefore still a very old map about an empowering state of 'consciousness' perhaps best and most succinctly expressed by Garvey himself as 'Africa for the Africans both at home and abroad', which for many has meant fashioning and refashioning Africa consistently in those spheres we have occupied and dominated by our works.

\section{Notes}

1. See Silverberg (1972, pp. 73-86).

2. The population of the British West Indies along with the non-British CARICOM states (i.e., Haiti and Suriname) fifteen small island states, have a total population of approximately 15 million inhabitants, ninety percent of whom are of African decent, with yet another five percent (on average) of mixed descent (African and European/Asian). Information sourced from US Central Intelligence Agency, country profile see https.//www.cia.gov.library/ publications/theworld-fact-book/geos (retrieved September 9, 2008). Nettleford (2007) describes the region as 'where Africa, Europe and Asia met on Amerindian soil'.

3. If however mindful of Ivan Van Sertima's thesis - that the African presence predates that of the Europeans in the region by centuries - their hegemonic significance is borne out by the monuments (Olmec Negroid heads) erected to them in the Central American region.

4. Silverberg (1972, p. 73).

5. See King, K.J. (1978) as well as James, W. (1998) for comprehensive discussions of Ethiopianism within the African Diaspora and its manifestations in theWest as well as within the African continent in the early decades of the twentieth century.

6. See Edmonds (2003).

7. See Lee (2003) and Hill (2001) for discussion of Howell and the early Rastafari leadership. Elkins (1977) provides a discussion of 'Street Preachers' in Jamaica from the late nineteenth century to the early decades of the twentieth century. The streets can be viewed as a genuine 'theatre for debate' and discursive deliberations, or what Rastafari lexicon would call a space for 'reasoning', or what obtains in the literature as 'public sphere', especially for the marginal most - without resources to secure favour of policy makers or media. To this extent this forum of street ideational activism or 'reasoning' operates more akin to a 'counter-public' (see Fraser 1990) as it would be a critique of the bourgeois notion of public sphere expressed by Habermas (1989).

8. See Hill (2001).

9. Critics of Rastafari would perhaps highlight the Movement as more attractive to the andro-centric point of view along with being Afro-centric. 
10. See Carole Boyce Davies, 'Deportable Subjects: US Immigration Laws and the criminalizing of Communism', South Atlantic Quarterly, 100: 4 (2001).

11. In this regard see Angela Davis's extensive discussions on the USA's Prison Industrial Complex: http://www.time.com/time/community/transcripts/ chattr092298.html.

12. See Bankie (2003) who debates the context of Pan Africanism or Continentalism.

13. 'Overstanding' is a Rastafari coinage to explain having knowledge of something, this is seen as more logical than the word 'understanding'.

14. See report in the Daily Gleaner, April 23, 1961. Also located in ARI project.

15. Eye witnesses say that this visit is unequalled in the history of Jamaica as far as national response - perhaps only rivalled by the visit of Nelson Mandela in recent times. Other African leaders who have made state visits to Jamaica are: William Tubman (1954); Kenneth Kaunda (1966); Julius Nyerere (1974); Chief Leabua Jonathan (1974); Samora Machel (1977); Nelson Mandela (1991); Gerry Rawlings (1996); Robert Mugabe (1996); Olusegun Obasanjo (2002 \& 2005); Thabo Mbeki (2003); Jakaya Mrisho Kikwete (2009).

16. See Fraser (1992) who engages the idea of the counter-public.

17. See Van Dijk, 1993, p. 94

18. Ibid.

19. Planno (1998) 'Polite Violence'.

20. See Davis (2006, pp. 211-215).

21. The Rastafari most sacred ritual, the 'Nyahbinghi', is a syncretic practice which has emerged in Jamaica over the last seventy years, drawing from the Eastern African tradition of colonial resistance through recourse to a spirit medium commanded by 'Queen Nyahbinghi'. This medium was perceived as the reason for the successful defence of the territory. Until her capture in the 1920s, she had the ability to inspire warriors to victory (see Hopkins, 1971). By some accounts Marley commanded such powers, and was thus recognized as a medium himself. Talamon (1994) refers to Marley as 'spirit dancer'; Chevannes (1999), as the 'apotheosis of Rastafari hero'. Marley is now considered a very powerful and unique African teacher and messenger.

\section{References}

Bankie, B.F., 2003, 'Mortimo "Bro Cummie" Planno: The Pan African Nationalist I Know', unpublished paper, made available by author.

Bayen, M.E., 1937, The Ethiopian World Federation Incorporated, Constitution \& By-Laws, August 25, 1937, New York.

Boyce, D.C., 'Deportable Subjects: US Immigration Laws and the Criminalizing of Communism', South Atlantic Quarterly, 100: 4 (2001).

Boyce, D.C. \& M'Bow, B., 2007, 'Towards African Diaspora Citizenship: politicizing an Existing Global Geography', Black Geographies and the Politics of Place, McKittrick and Woods, eds., pp. 14-45, Cambridge, Mass., Between the Lines \& South End Press. 
Brodber, E., 1996, 'Re-engineering Black Space', Plenary presentation at the Conference on Caribbean Culture, UWI, Mona.

Campbell, H., 1987, Rasta and Resistance: From Marcus Garvey to Walter Rodney, Trenton, N.J.: Africa World Press.

Chamberlin, J.E., 1999, 'A Map of the World', Index on Censorship (4), 110-111.

Chevannes, B., 1998, Rastafari and Other African-Caribbean Worldviews, First Edition, New Jersey: Rutgers University Press.

Chevannes, B., 1999, 'Between the Living and the Dead: the Apotheosis of Rastafari Hero', in J. Pulis, ed., Religion, Diaspora and Cultural Identity (pp. 337-356), Amsterdam: Gordon and Breach.

Dawes, K., 1999, [2004]). Natural Mysticism: Towards a New Reggae Aesthetic in Caribbean Writing, Leeds, Great Britain: Peepal Tree Press

Dijk, F.J. van, 1993, Rastafari and Jamaican Society 1930-1990, First Edition, Utrecht: ISOR.

Edmonds, E., 2003, Rastafari: from Outcast to Culture Bearers, Oxford: New York University Press.

Elkins, W.F., 1972, 'Marcus Garvey and the Negro World', (pp. 29-45), in W.F. Elkins, ed., Black Power in the Caribbean: The Beginning of the Modern National Movement, Brooklyn: Revisionist Press.

Elkins, W.F., 1977, Street preachers, Faith Healers, and Herb Doctors in Jamaica, 1890-1925, New York: Revisionist Press.

Fanon, F., 1966, The Wretched of the Earth, Middlesex, England: Penguin.

Friere, P., 2003, Pedagogy of the Oppressed, New York: Continuum International Publishing Group, and London.

Garvey, A.J., 1986, The Philosophy and Opinions of Marcus Garvey, or, Africa for the African, Dover, Massachusetts: The Majority Press.

Gifford, A., 2000, 'The Legal Basis of the Claim for Slavery Reparations', Human Rights: Journal of the Section of Individual Rights and Responsibilities, 27(2), 16, 3p, 1 bw.

Government of Jamaica, 1961, Mission to Africa Report, Kingston: Government of Jamaica Printer.

Haile Selassie I University Office of Public Relations, 1964, Academic Honours of His Imperial Majesty Haile Selassie I Emperor of Ethiopia: A Commemorative Volume 1924-1963. Addis Ababa: Ethiopia.

Hickling, F., 2004, 'Popular Theatre as Psychotherapy', Interventions: International Journal of Post-Colonial Studies. 6: 1, pp. 54-57.

Hill, R., 2001, Dread History: Leonard Howell and Millenarian Visions in the Early Rastafari Religion, Research Association School Times Publication/ Frontline Distribution Intl' Inc., Kingston, Jamaica.

Homiak, J.P., 1999, 'Movements of Jah People: From Sound Scapes to Mediascape', in John Pullis, ed., Religion, Diaspora and Cultural Identity: A Reader in the Anglophone Caribbean, pp. 87-123. Amsterdam: Gordon and Breach. 
Hopkin, E., 1971, 'The Nyabingi Cult of Southwestern Uganda', in R.I. Rotberg, ed., Protest and Power in Black Africa (pp. 60-132), Oxford: Oxford University Press.

Howell, L.P., ([1935]), The Promised Key, Kingston: Headstart Printing \& Publishing Co. Ltd.

James, W., 1998, Holding Aloft the Banner of Ethiopia: Caribbean Radicalism in Early Twentieth-Century America, First Edition, London \& New York: Verso.

King, K.J., 1978, 'Some Notes on Arnold J. Ford and New World Black Attitudes to Ethiopia', in Burkett \& Newman, eds., Black Apostles: Afro-American Clergy Confronts the Twentieth Century, pp. 49-55, Boston: G. K. Hall.

Lee, H., 2003, The First Rasta: Leonard Howell and the Rise of Rastafarianism, Chicago: Review Press.

Nettleford, R., 1972, Identity, Race and Protest in Jamaica, New York: William Morrow \& Company.

Niaah, J., 2005, 'Absent Father(s), Garvey's Scattered Children and the Back to Africa Movement', Lead chapter in Negotiating Modernity, Africa's Ambivalent Experience, Elisio Salvado Macamo, ed., CODESRIA Africa in the New Millennium series, ZED Publisher.

Niaah, J., 2003, 'Poverty (lab)Oratory: Rastafari and Cultural Studies', Cultural Studies, 17(6), 24-842.

Planno, M., 1979, 'The Truth About the Rastafari Movement as told by Brother Cummie', [Interview by] Tam Fiofori for Spear, Nigeria.

Planno, M., 1983, 'Head Decay Shuns Needs an Autopsy', presented at York University. Toronto: Canada (unpublished).

Planno, M., 1996, Earth's Most Strangest Man: the Rastafarian, New York: Institute for the Study of Man.

Planno, M., 1998a, 'Polite Violence', Folk Filosofi Series [Audio cassette recording], Library of the Spoken Word, UWI, Mona.

Planno, M., 1998b, 'Bob Marley, Christ and Rastafari: the New Faculty of Interpretation', [Audio cassette recording], Library of the Spoken Word, UWI, Mona.

Planno, M., 1999, 'From the Cross to the Throne: Rastafari in the New Millennium', [Audio cassette recording], Library of the Spoken Word, The University of the West Indies, Mona.

Price, C.R., 2003, 'Cleave to Black: Expressions of Ethiopianism in Jamaica', New West Indian Guide, 77 (1\&2), pp. 31-64.

Reckord, V., 1982, 'Reggae, Rastafarianism and Cultural Identity', Jamaica Journal, 46,3-11.

Rodney, W., 1990, The Groundings with my Brothers, Chicago: Research Associate School Times Publications.

Rodney, W., 1981, How Europe Underdeveloped Africa, Second Edition, Washington DC: Howard University Press. 
Salter, R., 2001, 'Rastafari in a Global Context: Affinities of "Orthognosy" and "Oneness" in the Expanding World', (unpublished, made available by Arthur Newland).

Silverberg, R., 1972, The Realm of Prester John, New York: Doubleday \& Company. Simpson, G., 1962, 'The Ras Tafari Movement in Jamaica in Its Millennial Aspect', in S. Thrupp, ed., Millennial Dreams in Action: Essays in Comparative Study, (pp. 160-165), The Hague: Mouton.

Simpson, G., 1992, 'Reflections on the Rastafari Movement in Jamaica - West Kingston in the 1950s', Jamaica Journal, 25(2), pp. 3-10.

Smith, M.G., Augier, R. \& Nettleford, R., [1960] 1988, The Ras Tafari Movement in Kingston, Jamaica, Kingston: Institute for Social and Economic Research.

Talamon, B.W., 1994, Bob Marley: Spirit Dancer, West Indies Publishing Limited, Kingston.

Wynter, S., 1995, 'The Pope must have been Drunk the King of Castile a Madman: Culture as Actuality, and the Caribbean Rethinking Modernity', in Taiana, Alvina Ruprecht \& Cecilia, eds., The Reordering of Culture: Latin America, the Caribbean and Canada in the Hood, First Edition, Carleton: Carleton University Press.

Yawney, C., 1999, 'Only Visitors Here: Representing Rastafari into the 21st Century', in J. Pulis, ed., Religion, Diaspora, and Cultural Identity, Amsterdam: Gordon and Breach.

Yawney, C., 2001, 'Exodus: Rastafari, Repatriation, and the African Renaissance', African Century Publications Series, No. 4, Pretoria. 
